(1976) The medical model of the disease concept. British Journal of Psychiatry, 128, 588-94.

LEwIS, A. J. (1963) Medicine and the affictions of the mind. British Medical Journal, ii, 1547-49.

- (1966) In Price's Textbook of the Practice of Medicine, 10th ed. p. 1153. London: Oxford University Press.

Newsome, A. (1980) Doctors and counsellors: collaboration or conflict? Bulletin of the Royal College of Psychiatrists, 102. 4.

Roth, M. (1973) Psychiatry and its critics. British Journal of Psychiatry, 122, 373-78.
SCADDEN, J. G. (1967) Diagnosis: the clinician and the computer. Lancet, $i$, 877-82.

Slater, E. \& RoTh, M. (1969) Mayer-Gross Slater and RothClinical Psychiatry. 3rd ed. p. 6-7. London: Baillere Tindall and Cassel.

Whrrlock, F. A. (1977) Psychiatric epidemology: its uses and limitation. Australian and New Zealand Journal of Psychiatry, 11.1, 9-18.

Znboorg, G. (1941) A History of Medical Psychology. New York: W. W. Norton.

\title{
Correspondence
}

\section{Statutory registration of psychotherapists}

Dear Sir,

It sometimes seems that the tower-block elitism and the rococo fancies of certain schools of psychotherapy are matched only by the wilful and gothic misunderstandings evinced by their opponents and detractors. Professor Shepherd's dexterous survey (November Bulletin, p 166) of this area is more comprehensive than constructive, appearing to threaten beliefs and practices that have demonstrated their value (if also their failings) over years. Dr Sutherland's Psychodynamic Image of Man (1980), for example, attempts to provide a liberal and logical framework within which psychiatrists and other care-givers can operate, become aware of their own and others' 'complexes', and develop ways of helping those whose troubles, being often irrational, fail to respond to strictly 'scientific' approaches. But, if even the simple assertion is not acceptable that the art of psychotherapy demands a much more intimate personal involvement than, say, the learning of French or a surgical technique, and that the experience involves personal change in the therapist, then the whole debate on training and recognition becomes a futility. Yet, in these matters, wise decisions were never more necessary. For example, it should be possible to reach a wide agreement about the important, even central, role of psychoanalysis in the training of psychotherapists, without accepting claims that are arrogant or exclusive.

The Ross Clinic

J. K. W. MORRICE

Cornhill Road

Aberdeen AB9 2ZF

REFERENCE

Sutherland, J. D. (1980) The Psychodynamic Image of Man. Aberdeen University Press.

\section{Psychiatric opportunities in New Zealand \\ DeAr Sir,}

I have recently returned from four months as a visiting consultant in New Zealand, and while there became aware of quite exceptional clinical opportunities for well-trained general psychiatrists interested in taking responsibility for a comprehensive service, and also for psychotherapists and academically-minded psychiatrists. One position might well offer scope for a major piece of action research, with a controlled experiment into community versus hospital-based psychiatry. I should be pleased to correspond or meet with any member of the College who would like to know more about these positions, and perhaps offer some liaison with appropriate people in New Zealand.

\section{Queensdale Road}

London W11 4QD

Richard Crocket

\section{The Conservation Society}

DeAr Sir,

The Conservation Society has a small 'Psychological Working Party' whose object is to discover areas where psychological understanding can contribute to the effectiveness of practical or educational aspects of conservation. We meet thrice annually on a Saturday in NW London and I shall be glad to hear from any peychiatrist who may be interested to join us.

65 Fiery Hill Road

DAVID T. MACLAY

Barnt Green

Birmingham, B45 8JX 